\title{
BOOK TAX DIFFERENCE DAN FAKTOR-FAKTOR YANG MEMPENGARUHINYA
}

\author{
Dwi Fionasari ${ }^{1}$, Rama Gita Suci $^{2}$, Syahdan Setiawan ${ }^{3}$ \\ Universitas Muhammadiyah Riau. \\ dwifionasari@umri.ac.id
}

\begin{abstract}
In this study discussing the topic of interest currently in the field of tax accounting is about book tax difference. With the aim of knowing the influence between earning management, liquidity, and tax management on book tax difference. The study predicts that companies with high earning management, high liquidity, and high tax management will have a high tax difference as well. The total population in this study was 406 service companies and samples that will be used as many as 165 service companies listed on the indonesia stock exchange (IDX) period 2017-2019. Data analysis using SPSS 20 and Structural Equation Modeling Partial Least Square (SEM-PLS) using Warppls 6.0 software. The results of this study found that earning management had a negative and significant effect on book tax difference, liquidity had no effect on book tax differrence, and tax management had a positive and significant effect on book tax difference.
\end{abstract}

Keywords: book tax difference, service company, earning management, liquidity, tax management.

\begin{abstract}
Abstrak
Dalam penelitian ini membahas topik menarik perhatian saat ini di bidang akuntansi perpajakan ialah mengenai book tax difference. Dengan tujuan menguji pengaruh antara earning management, likuiditas, dan tax management terhadap book tax difference. Penelitian ini memprediksi bahwa perusahaan yang memiliki earning management yang tinggi, likuiditas yang tinggi, dan tax management yang tinggi akan memiliki book tax difference yang tinggi pula. Jumlah populasi dalam penelitian ini sebanyak 406 perusahaan jasa dengan sampel yang akan digunakan sebanyak 165 perusahaan jasa yang terdaftar di bursa efek indonesia(BEI) periode 2017-2019. Adapun analisis data menggunakan SPSS 20 dan Structural Equation Modeling - Partial Least Square (SEM-PLS) menggunakan software Warppls 6.0. Hasil dari penelitian ini menemukan bahwa earning management berpengaruh negatif dan signifikan terhadap book tax difference, likuiditas tidak berpengaruh terhadap book tax differrence, dan tax management berpengaruh positif dan signifikan terhadap book tax difference.
\end{abstract}

Kata kunci: book tax difference, perusahaan jasa, earning management, likuiditas , tax management. 


\section{Pendahuluan}

Laporan keuangan merupakan salah satu komponen penting dalam berdirinya suatu perusahaan. Dimana laporan keuangan digunakan pihak yang berkepentingan untuk melihat kondisi perusahaan tersebut. Dalam sebuah laporan keuangan perusahaan terdapat dua versi laba yaitu laba akuntansi dan laba fiskal (Irda and Ikhsan, 2018). Perbedaan perhitungan laba timbul karena ketentuan dan konsep yang berbeda antara SAK dan undang-undang perpajakan. Karena perbedaan konsep dan ketentuan tersebut antara laba akuntansi dan laba fiskal sering disebut dengan book tax differences (BTD) (Rachmawati and Martani, 2014).

Book tax difference terbagi menjadi dua tipe yaitu BTD yang bersifat temporer dan BTD yang bersifat permanen. Perbedaan tetap atau permanen terjadi karena transaksi transaksi pendapatan dan biaya diakui menurut akuntansi komersial dan tidak diakui menurut fiskal atau sebaliknya (Tampubolon and Kartikaningdyah, 2016). Perbedaan temporer atau sementara terjadi karena perbedaan waktu pengakuan pendapatan dan biaya dalam perhitungan laba.

Tentu saja hal ini juga berpengaruh terhadap besaran laba fiskal perusahaan. Maka itu tidak jarang perusahaan melakukan beberapa kebijakan untuk mengecilkan kewajiban pajak mereka, seperti memanajemen laba perusahaan, manajemen pajak perusahan bahkan memanipulasi laba perusahan. Seperti yang dilakukan PT. Asuransi Jiwasraya dimana menurut Badan Pemeriksa Keuangan (BPK) menyatakan perusahaan Asuransi Jiwasraya pernah mencatat laba pada tahun 2006. Namun laba tersebut ternyata hanya laba semu alias laporan keuangan yang dimanipulasi dari rugi menjadi untung. Hal itu juga disampaikan oleh agung di depan gedung BPK "pada tahun 2006, jiwasraya mencatat laba, tetapi itu laba semu akibat rekayasa akuntansi”. (www.liputan6.com, Januari 2020). Sampai Tahun 2017 perusahaan mencatat laba sebesar Rp. 360,6 miliar. Namun mendapat opini kurang wajar karena adanya kekurangan pencadangan sebesar Rp. 7,7 Triliun hingga pada tahun 2018 bpk mengungkap bahwa Asuransi Jiwasraya rugi Rp. 15,3 Triliun. Hingga November 2019, Jiwasraya memiliki negatif equity sebesar Rp. 27,2 triliun (www.liputan6.com, Januari 2020).

Manipulasi laporan keuangan yang terjadi di perusahaan Asuransi Jiwasraya tentu saja juga merubah book tax difference perusahaan tersebut sehingga membuat perusahaan membayar kewajiban pajak yang tidak sesuai dengan yang seharusnya. Secara umum, banyak faktor yang dapat mempengaruhi book tax difference suatu perusahaan. Salah satunya adalah earning management. Manajemen laba dapat didefinisikan sebagai salah satu pilihan yang 
diambil manajer terkait kebijakan akuntansi dalam rangka mencapai tujuan tertentu (Scott, 2009).

Hasil penelitian dari (Pohan, 2009), (Bahrainah, 2013), dan (Irda and Ikhsan, 2018) menyimpulkan bahwa earning management berpengaruh terhadap perubahan book tax difference. Hasil penelitian mereka bertolak belakang dengan penelitian yang dilakukan (Sitorus and Lawahizh, 2019) yang menyimpulkan bahwa earning management tidak berpengaruh terhadap book tax difference.

Faktor berikutnya yang dapat mempengaruhi book tax difference adalah likuiditas. Likuiditas merupakan kemampuan sebuah perusahaan untuk melunasi kewajiban hutangnya terutama kewajiban jangka pendek. Hasil penelitian (Tampubolon and Kartikaningdyah, 2016) dan (Aziziyah, 2017) menyimpulkan bahwa likuiditas perusahaan tidak berpengaruh terhadap BTD. Hasil penelitian mereka bertolak belakang dengan penelitian yang dilakukan (Raudhah and Saleh, 2018) yang menyimpulkan bahwa likuiditas berpengaruh terhadap book tax difference.

Kemudian faktor berikutnya yang dapat mempengaruhi book tax difference ialah tax management. Tax management merupakan tindakan perusahaan untuk memaksimalkan perpajakan dimana pajak yang dibayarkan dapat secara efektif dan efisien. Hasil penelitian dari (Bahrainah, 2013) dan (Sitorus and Lawahizh, 2019) menyimpulkan bahwa tax management berpengaruh kepada book tax difference. Hasil penelitian mereka bertolak belakang dengan penelitian yang dilakukan (Ayundasari, 2016) yang menyimpulkan bahwa tax management tidak berpengaruh terhadap book tax difference.

Penelitian ini merupakan pengembangan dari penelitian yang dilakukan oleh (Sitorus and Lawahizh, 2019) perbedaan penelitian ini dengan penelitian sebelumnya adalah peneliti tidak menggunakan variabel pengawasan komite audit sebagai variabel moderasi dikarenakan variabel tersebut tidak memperkuat hasil pada penelitian sebelumnya. Dalam penelitian ini juga menambahkan satu variabel yaitu likuiditas dari peneliti (Raudhah and Saleh, 2018) dimana alasan peneliti menambahkan variabel tersebut karena layak diteliti bersama variabel lainnya. Perbedaan penelitian selanjutnya yaitu pada objek penelitian dimana (Sitorus and Lawahizh, 2019) melakukan penelitian di perusahaan properti yang listing di Bursa Efek Indonesia sedangkan di penelitian ini meneliti objek di perusahaan jasa yang listing di Bursa Efek Indonesia. Perusahaan Jasa dipilih karena di asumsikan perusahaan jasa memiliki 
kuantitas yang besar sehingga dapat memberikan kontribusi besar terhadap pembayaran pajak penghasilan pajak.

\section{Tinjauan Literatur}

\section{Teori Keagenan (Agency Theory)}

Agency Theory (Teori Keagenan) adalah hubungan keagenan timbul di antara dua pihak dimana satu pihak yang disebut agen (agent) bertindak atas kepentingan pihak lainnya yang disebut pemilik perusahan / pemegang saham (principal) untuk melakukan tindakan pengambilan keputusan (Ross, 1973). Dimana yang bertindak sebagai agen ialah seorang manajer perusahan dia memiliki tanggung jawab untuk memenuhi kepentingan principal. Teori agensi (agency theory) adalah hubungan atau kontrak antara principal dan agen dimana diasumsikan bahwa tiap- tiap individu semata- mata termotivasi oleh kepentingan dirinya sendiri sehingga menimbulkan konflik kepentingan antara principal dan agent (Tampubolon and Kartikaningdyah, 2016).

Berkaitan dengan keagenan, praktik pelaporan keuangan perusahaan merupakan suatu konsep yang dimana didasari oleh teori keagenan. Dalam melaporkan laporan keuangan, perusahaan atau dalam hal ini manajemen bertindak sebagai agen. Sebagai agen perusahaan memiliki kewajiban untuk menyampaikan informasi yang bermanfaat bagi para stakeholder, dimana para stakeholder berperan sebagai principal.

\section{Metode Penelitian}

Pada penelitian ini, terdiri atas variabel dependen dan variabel independen. Variabel dependennya yaitu book tax difference. Menurut (Rachmawati and Martani, 2014) perbedaan perhitungan laba timbul karena ketentuan dan konsep yang berbeda antara SAK dan undangundang perpajakan. Karena perbedaan konsep dan ketentuan tersebut antara laba akuntansi dan laba fiskal sering disebut dengan Book tax differences (BTD). Pengukuran variabel book tax difference diambil dari penelitian Sitorus and Lawahizh (2019) dimana berpedoman pada penelitian yang dilakukan Tang, T. Y. H., \& Firth (2012) untuk mengukur Book tax difference.

$$
\mathrm{BTD}=\frac{\text { Laba Komersial }- \text { Laba Fiskal }}{\text { Total Aset }}
$$


Selanjutnya, variabel independen pada penelitian ini terdiri dari earning management, likuiditas, dan tax management. Manajemen laba (Earning Management) adalah fenomena yang sulit dihindari, karena fenomena ini merupakan dampak dari penggunaan dasar akrual dalam penyusunan laporan keuangan (Raudhah and Saleh, 2018).

Proxy yang digunakan untuk mengukur mengacu pada penelitian sebelum yaitu (Sitorus and Lawahizh, 2019) dimana Earning Management diukur menggunakan Metode Modified Jones, dimana Manajemen laba diukur melalui Discretionary Accruals (DA) yang dihitung dengan cara menselisihkan Total Accruals (TA) dan Nondiscretionary Accruals (NDA).. Dimana metode modified Jones dirumuskan dengan:

\section{TACCit $=$ net income - operating cash flow}

Dari persamaan $T A$ tersebut, kemudian diestimasi dengan metode Ordinary Least Square $(O L S)$. Estimasi $\alpha 1, \alpha 2, \alpha 3$ didapat dari regresi $O L S$ tersebut dan digunakan untuk menghitung NDA sebagai berikut:

\section{NDAit $=a 1(1 T A i, t-1)+a 2(\triangle R E V i t-\triangle R E C i t) T A t-1+a 3(P P E i t T A t-1)+\varepsilon$}

Setelah itu menghitung nilai $D A$ dengan rumus berikut:

\section{DAit = TACCit - NDAit}

\section{Keterangan:}

TACCit = Laba bersih perusahaan i pada akhir tahun $\mathrm{t}$, dikurangi operating cash flow atau arus kas operasi perusahaan i pada periode $t$

TAi,t-1 = Total aset perusahaan i pada tahun akhir tahun $\mathrm{t}-1$

REVit = Perubahan dalam pendapatan operasi perusahaan $i$ pada akhir tahun $t$, dibagi total aset perusahaan i pada akhir tahun $t$

RECit = Perubahan dalam piutang bersih perusahaan $i$ pada tahun $t$, dibagi total aset perusahaan i pada akhir tahun $t$

PPEit = Nilai aktiva tetap (gross) perusahaan $\mathrm{i}$ pada tahun $\mathrm{t}$, dibagi total aset perusahaan i pada akhir tahun $\mathrm{t}$

NDAit $=$ Non akrual kelolaan perusahaan i pada periode $\mathrm{t}$

DAit $\quad=$ Akrual kelolaan perusahaan $i$ pada periode $t=$ Error term

Likuiditas adalah rasio kemampuan suatu perusahaan untuk memenuhi kewajiban finansialnya yang harus segera dipenuhi dalam jangka pendek sehingga sudah jatuh tempo hutang perusahaan dapat untuk melunasinya (Raudhah and Saleh, 2018). Pengukuran yang digunakan mengikuti peneliti sebelumnya (Tampubolon and Kartikaningdyah, 2016) yaitu untuk mengukur likuiditas adalah:

$$
\text { Likuiditas }=\frac{\text { Aktiva Lancar }}{\text { Utang Lancar }}
$$


Tax management merupakan segenap upaya untuk mengimplementasikan fungsifungsi manajemen agar pelaksanaan hak dan kewajiban perpajakan berjalan efektif dan efisien (Pohan, 2009). Proxy atau pengukuran yang digunakan mengikuti penelitian sebelumnya oleh (Sitorus and Lawahizh, 2019) ialah:

$$
\mathrm{ETR}=\frac{\text { Beban Pajak }}{\text { Laba Sebelum Pajak }}
$$

Populasi adalah generalisasi yang terdiri atas objek atau subjek yang mempunyai kualitas dan karakteristik tertentu yang ditetapkan oleh peneliti untuk dipelajari dan kemudian ditarik kesimpulan (Sugiyono, 2015). Adapun populasi yang digunakan pada penelitian ini yaitu pada perusahaan jasa yang terdaftar di Bursa Efek Indonesia (BEI) Tahun 2017-2019 berjumlah 406 perusahaan. Berdasarkan teknik pengambilan sampel dengan metode purposive sampling dan sampel yang terdaftar, maka jumlah perusahaan yang menjadi sampel dalam penelitian ini berjumlah 55 perusahaan dengan jumlah observasi selama 3 tahun yaitu 165 sampel.

Pada penilitian ini menggunakan Warp PLS. PLS merupakan perhitungan optimal least square fit terhadap korelasi atau matrik varian. Selain itu PLS adalah model persamaan struktural (SEM) yang berbasis komponen atau varian. Menurut (Ghozali, 2014), estimasi parameter yang didapat dengan PLS dapat dikategorikan menjadi tiga. Pertama adalah weight estimate yang digunakan untuk menciptakan skor variabel laten. Kedua, mencerminkan estimasi jalur (path estimate) yang menghubungkan variabel laten dan antar variabel laten dan blok indikatornya (loading). Kategori ketiga, berkaitan dengan means dan lokasi parameter (nilai konstanta regresi) untuk indikator dan variabel laten. Untuk memperoleh ketiga estimasi ini, PLS menggunakan proses iterasi 3 tahap dan setiap tahap menghasilkan estimasi. Tahap pertama, menghasilkan weight estimate, tahap kedua menghasilkan estimasi untuk inner model dan outer model, dan tahap ketiga menghasilkan estimasi means dan lokasi (konstanta). 


\section{Hasil dan Pembahasan}

Uji statistik deskriptif memberikan gambaran dan deskripsi suatu data dilihat dari mean, minimum, maximum, dan standard deviation. Berdasarkan uji deskriptif variabel menunjukan perhitungan dari empat variabel yaitu:

Tabel 4.2

Hasil Uji Statistik Deskriptif Descriptive Statistics

\begin{tabular}{|c|c|c|c|c|c|}
\hline & $\mathrm{N}$ & Minimum & Maximum & Mean & Std. Deviation \\
\hline Earning $M$ & 139 & -.0093 & .0093 & .000414 & .0022392 \\
\hline Likuiditas & 139 & .2796 & 6.6241 & 1.727528 & 1.1722415 \\
\hline Tax M & 139 & .0000 & .7693 & .172593 & .1443000 \\
\hline B.T. Difference & 139 & -.0179 & .0576 & .012536 & .0149909 \\
\hline $\begin{array}{l}\text { Valid } \\
\text { (listwise) }\end{array}$ & 139 & & & & \\
\hline
\end{tabular}

Sumber: Hasil Olah data SPSS 20, 2020

Berdasarkan data di atas, nilai standar deviasi yang besar dibanding nilai rata-rata menunjukan bahwa data book tax difference dalam penelitian ini terdapat beberapa outlier (data yang terlalu ekstrim). Untuk variabel earning management, nilai standar deviasi yang besar dibanding nilai rata-rata menunjukan bahwa data earning management dalam penelitian ini terdapat beberapa outlier (data yang terlalu ekstrim). Kemudian, untuk variabel likuiditas, nilai rata- ratanya lebih tinggi dari nilai standar deviasi, sehingga mengindifikasikan bahwa hasil cukup baik. sehingga dapat disimpulkan penyebaran atau tidak adanya kesenjangan yang cukup besar dari data likuiditas menunjukan hasil yang baik. Selanjutnya, untuk variabel tax management, nilai rata- ratanya lebih tinggi dari nilai standar deviasi, sehingga mengindifikasikan bahwa hasil cukup baik. Sehingga dapat disimpulakan penyebaran atau tidak adanya kesenjangan yang cukup besar dari data likuiditas menunjukan hasil yang baik.

\begin{tabular}{cc}
\multicolumn{2}{c}{$\begin{array}{c}\text { Hasil Uji PLS } \\
\text { Uji Outer model } \\
\text { Convergent Validity } \\
\text { Tabel 4.3 } \\
\text { Outer Loading }\end{array}$} \\
\hline Variabel & Outer \\
\hline Earning M & 1.000 \\
Likuiditas & 1.000 \\
Tax M & 1.000 \\
Book Tax Difference & 1.000 \\
\hline Sumber : Data Sekunder Diolah Warppls 6.0, 2020
\end{tabular}


Nilai outer loading-nya dibawah 0,5 , sehingga semua indikator dinyatakan layak atau valid untuk digunakan dalam penelitian dan dapat digunakan untuk analisis lebih lanjut. Composite Reliability

Tabel. 4.4

Composite Reliability

\begin{tabular}{cc}
\hline Variabel & Composite Reliability \\
\hline Earning M & 1.000 \\
Likuiditas & 1.000 \\
Tax M & 1.000 \\
Book Tax Difference & 1.000 \\
\hline Sumber : Data Sekunder Diolah Warppls 6.0, 2020
\end{tabular}

Composite reliability semua variabel dalam penelitian $>0.7$. hasil ini menunjukan bahwa masing- masing variabel penelitian telah memenuhi Composite reliability sehingga dapat disimpulkan bahwa seluruh variabel memiliki tingkat reliabilitas yang tinggi.

\section{Cronbach Alpha}

Tabel 4.5

Cronbach Alpha

\begin{tabular}{cc}
\hline Variabel & Cronbach Alpha \\
\hline Earning M & 1.000 \\
Likuiditas & 1.000 \\
Tax M & 1.000 \\
Book Tax Difference & 1.000 \\
\hline Sumber : Data Sekunder Diolah Warppls 6.0,2020
\end{tabular}

Nilai cronbach alpha dari masing masing variabel dapat dilihat di tabel 4.5, dimana nilai cronbach alpha dari setiap variabel penelitian $>0.6$. Dengan demikian hasil ini dapat menunjukan bahwa setiap variabel penelitian telah memenuhi persyaratan penilaian cronbach alpha, sehingga dapat disimpulkan bahwa keseluruhan variabel memiliki tingkat reliabilitas yang tinggi.

\section{Discriminant Validity (Validitas Diskriminan)}

Tabel 4.6

Output Correlations among Latent Variables with Square Roots of AVEs

\begin{tabular}{ccccc}
\hline & X1 & X2 & X3 & Y \\
\hline X1 & $(1.000)$ & -0.145 & 0.015 & -0.061 \\
X2 & -0.145 & $(1.000)$ & -0.189 & -0.033 \\
X3 & 0.015 & -0.189 & $(1.000)$ & 0.428 \\
Y & -0.061 & -0.033 & 0.428 & $(1.000)$ \\
\hline
\end{tabular}

Sumber : Data Sekunder Diolah Warppls 6.0, 2020 
Setiap akar kuadrat AVE (angka-angka di dalam kurung) lebih tinggi daripada korelasi antar variabel pada kolom selain diagonal. Dengan demikian, outer model telah memenuhi syarat baik convergent validity maupun discriminant validity.

\section{Uji Goodness Of Fit (Innder Model)}

Tabel 4.7

\begin{tabular}{cc}
\multicolumn{2}{c}{ Nilai R-Square } \\
\hline Variabel & Nilai $\boldsymbol{R}$ - Square \\
\hline Book Tax Difference & 0.284 \\
\hline Sumber : Data Sekunder Diolah Warppls 6.0, 2020
\end{tabular}

Nilai $R$-Square untuk variabel Book Tax Difference adalah 0.284 Perolehan nilai tersebut menjelaskan bahwa presentase besarnya Book Tax Difference dapat dipengaruhi oleh earning management, likuiditas, dan tax management.

Tabel 4.8

\begin{tabular}{cc}
\multicolumn{2}{c}{ Nilai Q- Square } \\
\hline Variabel & Nilai $\boldsymbol{Q}$ - Square \\
\hline Book Tax Difference & 0.306 \\
\hline Sumber : Data Sekunder Diolah Warppls 6.0, 2020
\end{tabular}

Nilai Q-Square untuk variabel Book Tax Difference sebesar 0.306. Dengan demikian, dari hasil tersebut maka model penelitian ini dapat dinyatakan telah memiliki goodness of fit yang cukup baik.

\section{Uji Hipotesis}

Pengujian hipotesis dimaksudkan untuk membuktikan kebenaran dugaan penelitian atau hipotesis. Hasil korelasi antar konstruk diukur menggunakan Path Coefficients dan tingkat signifikansinya yang kemudian dibandingkan dengan hipotesis penelitian yang telah tertera di bab dua. Tingkat signifikansi yang dipakai dalam penelitian ini adalah sebesar 0.05 atau 5\%. Berikut ini merupakan gambaran model penelitian dan hasil dari effect size yang telah diperoleh berdasarkan pengolahan data: 


\section{Gambar 4.1}

Model penelitian

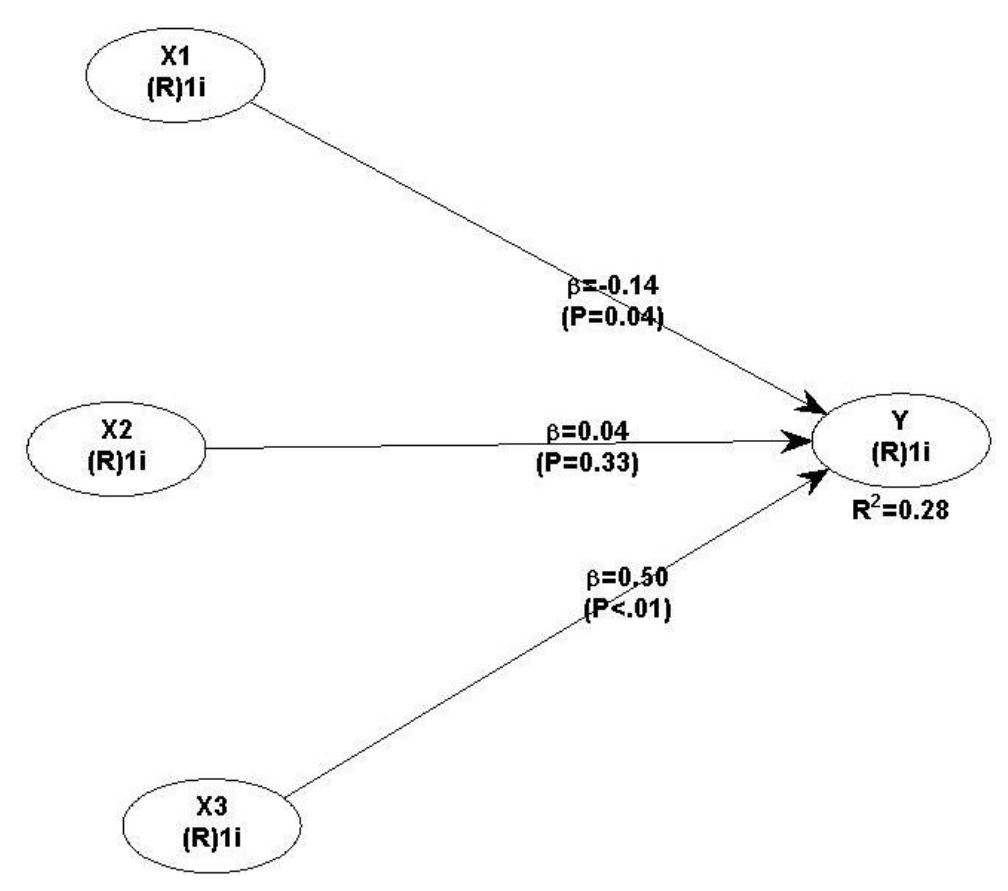

Sumber: Data diolah Warppls $6.0,2020$

Keterangan:
$\mathrm{X} 1$ : Earning Management
$\mathrm{X} 2$ : Likuiditas
$\mathrm{X} 3$ : Tax Management
Y : Book Tax Difference

Dari gambar 4.1 dapat dilihat bahwa hipotesis pertama dengan variabel earning management memiliki pengaruh yang signifikan terhadap book tax difference. Diketahui dari angka koefisien jalur yang memiliki nilai sebesar -0.14 dengan nilai P- value sebesar 0.04 dimana lebih kecil dari 0,05 atau 5\%. Berdasarkan hal tersebut menunjukan bahwa earning management mempengaruhi secara signifikan terhadap book tax difference. Jadi hipotesis pertama (H1) diterima dan didukung yang artinya earning management berpengaruh negatif dan signifikan terhadap book tax difference.

Hipotesis kedua, menunjukan bahwa variabel likuiditas terhadap book tax difference. dapat dilihat dari nilai koefisien jalur sebesar 0.04 dengan p-value sebesar 0.33 dimana nilainya lebih besar dari 0.05 . berdasarkan hal tersebut menunjukan bahwa variabel likuiditas tidak berpengaruh terhadap book tax difference. Jadi hipotesis kedua $(\mathrm{H} 2)$ ditolak atau tidak didukung yang artinya likuiditas berpengaruh positif tidak signifikan terhadap book tax difference. 
Hipotesis ketiga, menunjukan bahwa variabel tax management terhadap book tax difference dengan dilihat dari nilai koefisien jalur sebesar 0.50 dengan p- value sebesar < 0.001 dimana nilainya lebih kecil dari 0.05 . Berdasarkan hal tersebut menunjukan bahwa variabel tax management berpengaruh secara signifikan terhadap book tax difference. Jadi hipotesis ketiga (H3) dapat diterima dan didukung yang arti nya tax management berpengaruh positif signifikan terhadap book tax difference.

Hasil dari estimasi dari model penelitian dapat dilihat di tabel 4.9.

Tabel 4.9

Tabulasi Hasil Estimasi Dari Model Penelitian

\begin{tabular}{ccccc}
\hline Hipotesis & Variabel & $\begin{array}{c}\text { Koefisien Jalur } \\
(\boldsymbol{B})\end{array}$ & P- value & Keterangan \\
\hline $\mathrm{H} 1$ & $\mathrm{X} 1 \rightarrow \mathrm{Y}$ & -0.14 & 0.04 & Signifikan \\
\hline $\mathrm{H} 2$ & $\mathrm{X} 2 \rightarrow \mathrm{Y}$ & 0.04 & 0.33 & Signifikan \\
\hline $\mathrm{H} 3$ & $\mathrm{X} 3 \rightarrow \mathrm{Y}$ & 0.50 & $<0.01$ & Signifikan \\
\hline
\end{tabular}

Sumber : Data Sekunder Diolah Warppls 6.0, 2020

\section{Pembahasan}

\section{Pengaruh Earning Management Terhadap Book Tax Difference}

Agency Theory (Teori Keagenan) menurut (Ross, 1973) adalah hubungan keagenan timbul di antara dua pihak dimana satu pihak yang disebut agen (agent) bertindak atas kepentingan pihak lainnya yang disebut pemilik perusahan / pemegang saham (principal) untuk melakukan tindakan pengambilan keputusan. Hal ini berkaitan langsung dengan keputusan yang akan di ambil mana jemen dimana keputusan yang dipilih manajemen harus sesuai dengan kepentingan pemegang saham. Dalam penelitian ini dapat disimpulkan bahwa earning management memiliki pengaruh terhadap terhadap book tax difference . Dengan hasil ini didukung dengan teori agensi yang menjelaskan penyebab agent melakukan untuk manipulasi laba perusahaan. Tapi tak jarang juga muncul konflik antara agent dan principal sehingga agent tidak dapat memenuhin keinginan principal sepenuhnya.

Tetapi berkaitan dengan terdapat pengaruh negatif antara earning management terhadap book tax difference. Hal ini sesuai dengan Agency Theory dimana segala keputusan yang dilakukan oleh manajemen dilakukan untuk kepentingan pemilik perusahaan/ pemegang saham. Hal ini terjadi karena sudah adanya kontraktual antara manajemen dan pemilik perusahaan. Sehingga hal ini berkaitan dengan tindakan 
manajemen dalam mengambil sebuah keputusan, dimana keputusan tersebut akan sesuia dengan keinginan pemilik perusahaan atau tidak. Hasil penelitian ini sesuai dengan penilitian yang dilakukan (Pohan, 2009) dimana earning managemen berpengaruh negatif terhadap book tax difference.

\section{Pengaruh Likuiditas Terhadap Book Tax Difference}

Dapat disimpulkan bahwa, semakin tinggi atau rendahnya tingkat utang yang dimiliki perusahaan tidak mempengaruhi tingkat agresivitas pajak perusahaan. Menurut hasil penelitian (Aziziyah, 2017) jika likuiditas mengalami kenaikan, BTD tidak akan berpengaruh. Jadi, besar atau kecilnya likuiditas tidak akan mempengaruhi perilaku manajemen dalam melakukan upaya manajemen laba untuk mengurangi pajak. Dimana tingkat likuiditas perusahaan tidak mempengaruhi beda laba akuntansi dan laba fiskal (book tax difference), hal ini dapat terjadi karena untuk melakukan manajemen pajak tidak perlu melihat dari tingkat likuiditas suatu perusahaan untuk dapat melunasi hutang jangka pendeknya.

Berdasarkan hasil pengujian ini berarti hipotesis kedua tidak terdukung. Hal ini juga dapat disebabkan oleh data variabel likuiditas yang memiliki beberapa sampel dengan nilai yang ekstrim tingginya seperti pada perusahaan dengan kode INTD dimana likuiditas perusahaan pada tahun 2017 sebesar 16.31, tahunb2018 sebesar 14.56, dan tahun 2019 kembali menjadi 16.00 . Penalitian ini juga didukung dengan hasil penelitian yang dilakukan (Tampubolon and Kartikaningdyah, 2016) dan (Aziziyah, 2017) dimana dalam penelitian yang mereka lakukan membuktikan Likuiditas tidak berpengaruh terhadap book tax difference.

\section{Pengaruh Tax Management Terhadap Book Tax Difference}

Hasil ini telah sesuai dengan hipotesis bahwa tax management memiliki pengaruh terhadap book tax difference. Dari hasil analisis tersebut dapat diketahui hipotesis ketiga dapat diterima. Jika tax management semakin tinggi maka semakin besar peluang perusahaan melakukan book tax difference. dimana salah satu cara tax management yaitu dengan cara mengatur seberapa besar laba yang di laporkan, sehingga masuk dalam indikasi adanya praktik book tax difference terhadap laporan keuangan. 
Hal ini didukung juga dengan teori agensi dimana menjelaskan perihal penyebab agen melakukan manajemen perpajakan dimana hal ini dilakukan untuk menekan kewajiban perpajakan perusahaan untuk mengikuti keinginan pemegang saham (principal). Berdasarkan dari hasil olah data, penelitian pada perusahan dengan kode emiten INTD dimana kenaikan yang terjadi pada tax management akan menaikan BTD perusahaan, dari tahun 2017 tax management sebesar 0.359 dengan BTD sebesar 0.018, tahun 2018 tax management sebesar 0.372 dengan BTD sebesar 0.019, dan tahun 2019 tax management sebesar 0.650 dengan BTD sebesar 0.027. Menurut (Anggreni, 2017) aktivitas tax management di antaranya dengan adanya perbedaan laba akuntansi keuangan (financial accounting income) dengan laba kena pajak (taxable income) atau book-tax differences. Karena itu semakin besar laba akuntansi sebuah perusahaan dibanding laba fiskal nya maka dapat terindikasi perusahaan tersebut melakukan tax management. Dimana salah satu contoh manajemen perpajakan adalah dengan cara mengatur seberapa besar laba yang akan dilaporkan kepada fiskus, sehingga ini menjadi indikasi terjadinya book tax difference terhadap laporan keuangan perusahaan. Hasil temuan ini diperkuat dengan penelitian yang dilakukan oleh (Sitorus and Lawahizh, 2019) dimana hasilnya membuktikan bahwa tax management berpengaruh terhadap book tax difference

\section{Kesimpulan}

Berdasarkan hasil analisis data dan uji hipotesis , maka dapat disimpulkan bahwa:

1. Earning management memiliki pengaruh negatif dan signifikan terhadap book tax difference. Dapat disimpulkan dalam hasil penelitian ini earning management akan menurunkan book tax difference, dimana dapat diartikan managemen berupaya semaksimal mungkin agar pajak yang dibayar sesuai dengan ketentuan perundangundangan perpajakan dangan menerapkan akrual yang sesuai dengan ketentuan.

2. Likuiditas tidak memiliki pengaruh terhadap book tax difference. Dari hasil ini dapat disimpulkan jika likuiditas mengalami kenaikan, maka BTD tidak akan berpengaruh, dapat diartikan kecil besarnya likuiditas perusahaan tidak berpengaruh prilaku manajemen dalam melakukan upaya manajemen laba untuk mengurangi pajak.

3. Tax Management Memiliki pengaruh positif dan signifikan terhadap book tax difference. Dapat disimpulkan apa bila BTD meningkat maka tax management juga ikut meningkat 
dan hal ini dapat mengindifikasikan adanya manipulasi laba pada laporan keuangan perusahaan.

Berdasarkan penelitian yang telah dilakukan, serta pembahasan dan kesimpulan yang diperoleh maka saran yang dapat diberikan oleh peneliti adalah sebagai berikut:

1. Untuk peneliti selanjutnya, diharapkan menambah jumlah sampel atau menambah tahun observasi sehingga peneliti selanjutnya dapat mendapatkan hasil yang lebih maksimal lagi

2. Untuk Peneliti selanjutnya diharapkan menambahkan beberapa variabel yang dianggap dapat mempengaruhi book tax difference seperti: perusahaan afiliasi, pertumbuhan perusahaan, dan lain- lain.

3. Diharapkan untuk peneliti selanjutnya untuk menambahkan variabel-variabel yang memiliki kemungkinan dapat mempengaruhi book tax difference seperti perusahaan afiliasi, pertumbuhan pendapatan dan sebagainya. 


\section{Daftar Pustaka}

Anggreni, N. K. (2017) 'Pengaruh Tax Management Pada Kualitas Laba Dan Corporate Governance Sebagai Variabel Moderasi’, Jurnal Ilmiah Akuntansi dan Bisnis, 2(1).

Aziziyah, N. (2017) Pengaruh Profitabilitas, Likuiditas, Kualitas Laba Dan Penghindaran Pajak Terhadap Perbedaan Laba Akuntansi Dan Laba Fiskal (Book-Tax Difference) Pada Perusahaan Wholesale And Retail Trade. Univeristas Negeri Jakarta.

Ayundasari, S. M. (2016) Karakteristik Perusahaan, Manajemen Pajak (Effective Tax Rate), Dan Pengaruhnya Terhadap Book-Tax Differences Pada Perusahaan Manufaktur Yang Listed Di Bei. Universitas Negeri Jakarta.

Bahrainah (2013) Analisis Pengaruh Manajemen Laba Dan Manajemen Pajak Terhadap Book-Tax Difeerences Pada Perusahaan Manufaktur Di Indonesia. Universitas Indonesia.

Irda, P. I. and Ikhsan, A. E. (2018) 'Pengaruh Manajemen Laba, Leverage, dan Profitabilitas terhadap Book-Tax Differences (BTD) pada Perusahaan yang Terdaftar di Jakarta Islamic Index (JII)', Jurnal Ilmiah Mahasiswa Ekonomi Akuntansi (JIMEKA), 3(1), pp. 44-53.

Ghozali, I. (2014) Structural Equation Modeling Metode Alternatif dengan Partial Least Squares (PLS). Semarang: Universitas Dipenegoro Semarang.

Pohan, H. (2009) 'Pengaruh Ukuran Perusahaan, Manajemen Laba, Tarif Pajak Efektif, Perata Laba, Konservatisma Terhadap Beda Laba Akuntansi Dengan Laba Pajak', Media Riset Akuntansi. Auditing dan Informasi, 9(2), pp. 62-85.

Rachmawati, N. A. and Martani, D. (2014) 'Pengaruh Large Positive Abnormal Book-Tax Differences', 11(2), pp. 120-137.

Raudhah, L. A. and Saleh, M. (2018) 'Pengaruh Likuiditas, Perusahaan Afiliasi, Pertumbuhan Pendapatan, dan Manajemen Laba terhadap Book Tax Gap pada Perusahaan Non Financial yang Terdaftar di BEI Tahun 2011-2015', Jurnal Ilmiah Mahasiswa Ekonomi Akuntansi (JIMEKA), 3(4), pp. 650-662.

Ross, S. A. (1973) The Economic Theory of Agency: The principal's problem.The American Economic Review.

Sitorus, R. R. and Lawahizh, Y. N. (2019) 'Pengaruh Earning Management dan Tax Management terhadap Book-Tax Differences yang Dimoderasi oleh Pengawasan Komite Audit', Media Akuntansi Perpajakan, 4(1), pp. 28-44. Available at: http://journal.uta45jakarta.ac.id/index.php/MAP.

Scott, W. R. (2009) Financial accounting theory (5th ed.). Toronto: Pearson Education Canada.

Sugiyono (2015) Metode Penelitian Kombinasi (Mix Methods). Edited by Alfabeta. Bandung: Alfabeta.

Tampubolon, M. T. and Kartikaningdyah, E. (2016) 'Pengaruh Karakteristik Perusahaan Terhadap Book Tax Differences', Jurnal Akuntansi, Ekonomi dan Manajemen Bisnis, 4(1), pp. 52-59. 